\title{
Problematyka sądownictwa polubownego w rezolucjach Rady Nieustającej (1776-1788)
}

I. Pomimo znaczącej roli, jaką w rozstrzyganiu sporów między szlachtą odgrywały w I Rzeczypospolitej sądy polubowne ${ }^{1}$, w literaturze historyczno-prawnej pisano o nich stosunkowo niewiele ${ }^{2}$. Zasadne jest więc zwrócenie większej uwagi na podstawowe problemy związane $\mathrm{z}$ ich funkcjonowaniem, szczególnie w XVIII w., a więc w okresie wzrostu popularności tzw. kompromisów.

Genezy sądów polubownych należy jednak szukać znacznie wcześniej, co było związane ze znanym już w wiekach średnich postępowaniem polubownym, tzw. jednaniem ${ }^{3}$, wykształconym jako odpowiedź na prowadzącą do

1 Fakt ten potwierdzają przekazy pamiętnikarzy. Przykładem jest Marcin Matuszewicz, który wspomina o sądzie polubownym w sprawie swojej matki oskarżonej o przyczynienie się do śmierci szlachcica Łastowskiego (M. Matuszewicz, Diariusz życia mego, t. I, oprac. B. Królikowski, Z. Zielińska, Warszawa 1986, s. 189-192) czy Adam Moszczeński przytaczający przebieg kompromisu w sporze między stolnikiem koronnym Kajetanem Olizarem, a mężem jego siostry - Borkowskim, o wypłatę posagu (A. Moszczeński, Pamiętnik do historii polskiej, Warszawa 1905, s. 37-41)

2 O sądownictwie polubownym w okresie przedrozbiorowym pisali m.in.: S. Domino, Sąownictwo polubowne na Rusi w późniejszym średniowieczu, Warszawa 1938; A. Rosner, Tradycja staropolskiego sądownictwa polubownego - Próba zarysowania problemu, [w:] Sprawiedliwość naprawcza. Idea. Teoria. Praktyka, red. M. Płatek, M. Fajst, Warszawa 2005, s. 37-58; A. Moniuszko, A. Rosner, Historia polubownego rozwiąywania sporów na ziemiach polskich. Zarys problematyki, [w:] Mediacje. Teoria i praktyka, red. E. Gmurzyńska, R. Morek, Warszawa 2014, s. 53-67.

3 W tym miejscu wątpliwości budzi informacja podawana przez Teodora Ostrowskiego, który stwierdził, że sąd kompromisarski „dawniej w Litwie tylko znany, dopiero po roku 1776 w Koronie na rozpoznanie spraw nawet ziemskich przyjęty i pro inappellabili poczytany" (T. Ostrowski, Prawo cywilne albo szczególne narodu polskiego, t. II, Warszawa 1784, s. 82). Ostatnio zwrócił na to uwagę A. B. Zakrzewski, podkreślając, że sądy te istniały od dawna również w Koronie (A.B. Zakrzewski, Wielkie Księstwo Litewskie (XVI-XVIII w.). Prawo - Ustrój - Społeczeństwo, Warszawa 2013, s. 188). Co więcej - jak wynika z przekazu J. Kitowicza - w czasach Augusta III kompromisy były już zjawiskiem powszechnym (J. Kitowicz, Opis obyczajów za panowania Augusta III, Kraków 1951, s. 182-183), co jednoznacznie przeczy tezie stawianej przez Ostrowskiego. W Zbiorze Praw Sądowych Andrzeja Zamoyskiego (Warszawa 1778) jego autorzy wyraźnie podkreślili, że sąd polubowny był ,z dawna w narodzie używany” (Cz. III, art. XI, § 1). Sądownictwu polubownemu 
wzajemnego wyniszczenia rodów samopomoc ${ }^{4}$. Istotny wpływ na rozwój sądownictwa polubownego miał pogłębiający się, w szczególności w I połowie XVIII w., kryzys sądów szlacheckich pierwszej instancji ${ }^{5}$, głównie ziemstw, działających opieszale i nieregularnie, w niektórych województwach nieobsadzanych przez kilkanaście lub kilkadziesiąt lat ${ }^{6}$, a także duże zaległości w rozpoznawaniu spraw przez Trybunały ${ }^{7}$. Z pewnością znaczenie miały tu również wysokie koszty procesu sądowego, których strony starały się uniknąć ${ }^{8}$, a ponadto - o czym pisze O. Balzer i J. Michalski - faktyczna, bo związana ze środkami finansowymi, przewaga jednej ze stron procesu ${ }^{9}$, w rezultacie czego ofiarami w sporze $\mathrm{z}$ zamożną magnaterią padała uboga szlachta ${ }^{10}$. Ponadto w przypadku sądów polubownych zjawisko łapówkarstwa nie występowało na taką skalę, jak w przesiąkniętych korupcją ziemstwach czy Trybunałach ${ }^{11}$. Wreszcie A. Moniuszko i A. Rosner podkreślają rolę mocno ugruntowanej w kulturze politycznej szlachty tradycji polubownego rozwiązywania konfliktów, w której bardzo negatywnie postrzegano odmowę poddania się postępowaniu w drodze kompromisu ${ }^{12}$. Wszystkie te okoliczności sprzyjały tendencji przekazywania sporów do rozstrzygnięcia właśnie sądom polubownym, gwarantującym jeśli nie rychłe zakończenie, to przynajmniej stosunkowo szybkie rozpoczęcie samego postępowania.

poświęcono zresztą cały artykuł XI w części III („O sprawach”) dotyczącej organizacji sądownictwa i procedury sądowej. Więcej o projekcie kodeksu zob. E. Borkowska-Bagieńska, ,Zbiór praw sądowych" Andrzeja Zamoyskiego, Poznań 1986.

${ }^{4}$ J. Rafacz, Dawny proces polski, Warszawa 1925, s. 3. Dodajmy, że rozwiązywanie sporów w drodze kompromisów mogło przybrać formę: postępowania polubownego lub mediacji. Zob. więcej: A. Moniuszko, A. Rosner, Historia polubownego rozwiąywania sporów..., s. 54.

5 S. Płaza, Historia prawa w Polsce na tle porównawczym, cz. I, Kraków 2002, s. 557.

${ }^{6}$ J. Rafacz, Dawny proces..., s. 29.

7 W. Uruszczak, Historia państwa i prawa polskiego, t. I, Warszawa 2010, s. 263. Wspomniane zaległości wynikały z nadmiernego przeciążenia Trybunału sprawami mniejszej wagi, co już w wieku XVII wywołało wśród szlachty poważną dyskusję nad ograniczeniem jego kompetencji, W. Bednaruk, Trybunat Koronny. Szlachecki Sad Najwyższy w latach 1578-1794, Lublin 2008, s. 96. O kryzysie wymiaru sprawiedliwości i propozycjach jego reformy w II poł. XVIII w. zob. także J. Michalski, Reforma sądownictwa na sejmie konwokacyjnym 1764 roku, [w:] idem, Studia historyczne z XVIII i XIX wieku, t. I, Polityka i spoleczeństwo, Warszawa 2007, s. 27-43.

8 J. Bardach, Historia Państwa i Prawa Polski, t. I, Warszawa 1964, s. 554.

9 O. Balzer, Geneza Trybunału Koronnego. Studium z dziejów sądownictwa polskiego XVI wieku, Warszawa 1886, s. 76, J. Michalski, Studia nad reforma sadownictwa i prawa sadowego w XVIII w. Wrocław-Warszawa 1958, s. 46.

10 T. Korzon, Wewnętrzne dzieje Polski za Stanisława Augusta, t. IV, Kraków-Warszawa 1897, s. 9.

${ }^{11}$ Mimo to również w sądach polubownych zdarzały się przypadki przekupstwa. Jak relacjonuje wspomniany już Moszczeński, niejaki Gintowt - superarbiter kompromisu w sporze między Olizarem a Borkowskim - od obu stron przyjął odpowiednio cztery i sześć tysięcy złotych łapówki (choć jak podaje pamiętnikarz, wziąwszy drugą kwotę od Borkowskiego, pierwszą ,uczciwie” odesłał Olizarowi), A. Moszczeński, Pamiętnik ..., s. 40.

12 A. Moniuszko, A. Rosner, Historia polubownego rozwiązywania sporów..., s. 67. 
Opis sądów kompromisarskich znajdziemy m.in. u Wincentego Skrzetuskiego, który definiuje je w następujących słowach: „Kompromis jest sąd polubowny, że obie strony spór prawny z sobą wiodące, odstępując dobrowolnie od zwyczajnych krajowych jurysdykcyi, same sobie sędziów umawiają i rozsądzenie sprawy jakiej im zupełnie poddają"13. Istota kompromisów opierała się więc na procesowej zasadzie dyspozytywności ${ }^{14}$, pozwalającej stronom samodzielnie ustalać reguły procesu. W specjalnie zawieranej umowie musiało znaleźć się: zobowiązanie do przekazania sprawy sądowi polubownemu, oznaczenie przedmiotu sporu, składu sądu, sposobu rozstrzygnięcia sporu (ugoda lub wyrok), a także określenie sankcji na wypadek niewykonania wyroku ${ }^{15}$.

W myśl ogólnie przyjętej zasady każda ze stron sporu wyznaczała równą liczbę reprezentujących ją, a rekrutujących się zazwyczaj spośród najbliższych przyjaciól, arbitrów ${ }^{16}$ - najczęściej po dwóch ${ }^{17}$ - następnie zaś sami arbitrzy wybierali przewodniczącego, tzw. superarbitra, zwanego niekiedy obermanem $^{18}$. Jeśli $\mathrm{w}$ gronie sędziów polubownych nie było osoby znającej prawo, do trzymania pióra arbitrzy mogli dobrać pozbawionego głosu stanowczego jurystę, którego zadaniem było, poza udzielaniem rad w zakresie obowiązującego prawa, sporządzenie właściwego formalnie dekretu ${ }^{19}$.

Wskazując na właściwość przedmiotową sądów polubownych, Teodor Ostrowski pisał: „Wchodzi ten sąd we wszystkie sprawy, które po przyjaciel-

13 W. Skrzetuski, Prawo polityczne narodu polskiego, t. II, Warszawa 1787, s. 461.

14 S. Płaza, Historia prawa..., cz. I, s. 557.

15 A. Rosner, Tradycja..., s. 40. Umowę taką zawierano najczęściej w formie ustnej (w obecności świadków), choć znana była również pisemna, S. Domino, Sądownictwo..., s. 43. W tym drugim przypadku można mówić o tzw. zapisie na kompromis.

${ }_{16}$ Przy wyborze arbitra kierowano się przede wszystkim pozycją społeczną kandydata i autorytetem wśród lokalnej społeczności. Stąd bardzo często był nim magnat - patron szlacheckich klientów (tu za przykład posłużyć może kanclerz litewski, książę Michał Czartoryski, o którego funkcji superarbitra w jednym ze sporów pisze M. Matuszewicz, Diariusz..., s. 374) lub reprezentant średniej szlachty piastujący jeden z urzędów ziemskich. Znajomość prawa nie odgrywała w tym przypadku większej roli, A. Rosner, Tradycja..., s. 47. Warto zaznaczyć, że w role arbitrów wcielały się obok mężczyzn także, choć wyjątkowo, kobiety, o czym wspomina, podając przykłady z Rusi S. Domino, Sadownictwo..., s. 69.

17 Regułę taką przyjęto zresztą w „Zbiorze Praw Zamoyskiego”, art. XI § 1. Niemniej jednak, liczba arbitrów mogła kształtować się różnie: od dwóch do ośmiu lub więcej sędziów, S. Domino, Sądownictwo..., s. 62.

18 J. Bardach, Historia..., t. I, s. 554. O ile delegowanie własnych arbitrów nie stanowiło większej trudności, o tyle obsadzenie funkcji superarbitra, na którego kandydaturę musiały przystać obie strony, mogło być przedmiotem kontrowersji - przypadek braku porozumienia w kwestii wyboru superarbitra kompromisu, opisuje we wspomnianej wyżej sprawie A. Moszczeński, $P a-$ miętnik..., s. 38.

19 J. Kitowicz, Opis obyczajów..., s. 183. Sporadycznie, na różnych etapach postępowania polubownego, w roli pośrednika lub świadka pojawiała się także osoba woźnego sądowego - w jego przypadku dysponujemy jednak wyłącznie przykładami z okresu średniowiecza, Z. Rymaszewski, Czynności woźnego sądowego, Warszawa 2010, s. 369-371. 
sku między obywatelami kończyć się mogą"20. Nie brakowało jednak wyjątków. Poza nawiasem uprawnień sądów kompromisarskich pozostawać miało rozstrzyganie spraw granicznych między posesorami dóbr królewskich, zaś jak dodaje cytowany autor - ,w sprawach graniczno-ziemskich rzadka praktyka, aby je sąd ten poznawał i kończył"21. Nieco inaczej kwestię tę przedstawia Tadeusz Czacki. Co prawda i on stwierdza, że ,,wszystko co jest w mocy i prawnej woli człowieka, wolno poddać kompromisowi”, ale spod jurysdykcji sądów polubownych wyłącza: sprawy dotyczące osób trzecich (toczone bez ich zgody lub na ich szkodę), kryminalne, bo jak tłumaczy - „kara za zbrodnie należy do władzy rządowej, a nie do partykularnej" oraz przypadki nadużyć na urzędzie - „bo to rozeznanie należy do władzy publicznej”22. Na mocy konstytucji uchwalonej dla Wielkiego Księstwa Litewskiego w 1726 r. poza kompetencjami sądów polubownych pozostały: (oprócz kryminalnych) sprawy dotyczące skarbu publicznego i dóbr królewskich, sprawy instygatorskie i osób nieletnich ${ }^{23}$ reprezentowanych przez opiekunów, co należy tłumaczyć ochroną przed działaniami na szkodę pupila ${ }^{24}$. Na koniec dodajmy, że kodyfikacja Zamoyskiego zakładała, iż ,sądzone mogą być w tym sądzie polubownym wszelkie sprawy prywatne obywatelów własności dotykające jako to: o sukcesje, działy, posagi, długi i o pretensje", wyłączając sprawy kryminalne, osób trzecich oraz ,inne cywilne, okoliczności publiczne w sobie zawierające" 25 .

II. W 1776 r. powołana do życia rok wcześniej Rada Nieustająca ${ }^{26}$ wyposażona została w kompetencję do tłumaczenia prawa ${ }^{27}$. Mimo krytycznego stanowiska, jakie zajęła w tej sprawie opozycja - obawiająca się wzrostu pozycji nowej instytucji rządowej i wkraczania przez nią w obszar zarezerwowany dla władzy ustawodawczej i sądowniczej ${ }^{28}$ - uprawnienie to Rada realizowała nieprzerwanie do $1788 \mathrm{r}^{29}$ Przez okres dwunastu lat wydała bli-

20 T. Ostrowski, Prawo cywilne..., t. II, s. 82-83.

21 Ibidem

22 T. Czacki, O litewskich i polskich prawach, t. II, wyd. Kazimierza Turowskiego, Kraków 1861, s. 97.

23 J. Rafacz, Dawny proces..., s. 5.

24 A. B. Zakrzewski, Wielkie Księstwo Litewskie..., s. 187.

${ }^{25} \mathrm{Cz}$. III, art. XI, § 5.

${ }^{26}$ Zob. więcej: W. Konopczyński, Geneza i ustanowienie Rady Nieustającej, Kraków 1917; A. Czaja, Między tronem, buławą a dworem petersburskim. Z dziejów Rady Nieustajacej 1786-1789, Warszawa 1988.

27 Rozszerzenie uprawnień Rady wprowadzone zostało w drodze konstytucji „Objaśnienie ustanowienia Rady Nieustającej przy Boku Naszym”, VL VIII, fol. 849-850.

28 R. Łaszewski, Sejm Polski w latach 1764-1793, Poznań 1973, s. 16.

${ }^{29}$ W styczniu 1789 r. Rada Nieustająca została rozwiązana („Uchylenie Rady Nieustającej”, VL IX, s. 64). Mimo jej reaktywacji w 1793 r., nie została już wyposażona w uprawnienie do interpretacji ustaw, VL X, fol. 63. 
sko sześćset rezolucji, w których rozstrzygano wątpliwości wynikające z niejasności przepisów prawa ${ }^{30}$. Zapytania dotyczące ich interpretacji - w formie memoriałów, raportów sądowych lub not urzędowych - przesyłano do Kancelarii Generalnej Rady, skąd podług właściwości przekazywano je Departamentowi Sprawiedliwości. Opracowane w nim projekty rezolucji przedstawiano następnie na posiedzeniach plenarnych Rady, uchwalano ich przyjęcie i przesyłano do zainteresowanych stron. Zgodnie z założeniem ustawodawcy rezolucje miały charakter wiążący nie tylko w przypadkach przedkładanych pod rozstrzygnięcie konsyliarzy, ale też we wszystkich sytuacjach analogicznych, które miałyby miejsce w przyszłości ${ }^{31}$. Problematyka poruszana w rezolucjach była zróżnicowana. Pytania dotyczyły przede wszystkim organizacji i funkcjonowania sądownictwa, ale również prawa sądowego, głównie procesowego i prywatnego, w mniejszym stopniu kryminalnego ${ }^{32}$. W $1780 \mathrm{r}$. zdecydowano, mając na celu upowszechnienie orzecznictwa Rady, o publikacji rezolucji poświęconych interpretacji prawa. W ciągu kolejnych ośmiu lat wydano drukiem pięć tomów zbiorów obejmujących rozstrzygnięcia w zakresie jego thumaczenia $z$ lat $1776-1786^{33}$. Natomiast rezolucje wydane między 1786 a 1788 r., zachowane do niedawna jedynie w formie oryginalnych rękopisów protokołów ekspedycji publicznych ${ }^{34}$, opublikowane zostały w $2014 \mathrm{r}$. nakładem Wydawnictwa Uniwersytetu Łódzkiego ${ }^{35}$.

III. W analizowanych przez Radę wnioskach o interpretację prawa wielokrotnie pojawiała się tematyka sądownictwa polubownego. Mimo, iż formuła kompromisu dawała stronom praktycznie nieograniczoną swobodę w samodzielnym kształtowaniu treści zapisu - co w zasadzie oznaczało pełną kontrolę nad toczonym postępowaniem - funkcjonowanie sądów polubownych budziło wiele kontrowersji, czego wyrazem było dwadzieścia pięć poświęconych temu zagadnieniu rezolucji.

${ }^{30}$ Zob. więcej: M. Głuszak: Rezolucje interpretacyjne Rady Nieustającej, „Czasopismo Prawno-Historyczne", 2013, z. 2, s. 73-101.

31 Kwestia związania orzeczeniami Rady innych podmiotów w analogicznych przypadkach nie została wyrażona w ustawie sensu stricto. Problem ten budził wiele kontrowersji i był szeroko dyskutowany wśród politycznych elit, W. Skrzetuski, Prawo polityczne..., t. II, s. 469-470.

${ }^{32}$ M. Głuszak, Rezolucje...., s. 81-82.

33 Wydania rezolucji podjęła się warszawska Drukarnia Korpusu Kadetów Piotra Dufour. Pełna nazwa każdego z tomów brzmiała: Zbiór rezolucyi Rady Nieustajacej potrzebnych do wiadomości jurysdykcyi sadowych i obywatelów obojga narodów. Kolejne tomy ukazały się w latach 1780, 1784, 1785, 1786 i 1788.

${ }^{34}$ W związku ze zniesieniem Rady w 1789 r. zaniechano publikacji rezolucji uchwalonych w czasie jej ostatniej kadencji. Protokoły ekspedycji publicznych z lat 1786-1788 znajdują się w zasobach AGAD, tzw. Metryka Litewska, VII, 59, 61, 64, 65.

${ }^{35}$ Zbiór rezolucji interpretacyjnych Rady Nieustajacej z lat 1786-1788, oprac. M. Głuszak, Łódź 2014. 
Przegląd orzecznictwa Rady Nieustającej w tym zakresie wypada zacząć od budzącego pewne wątpliwości problemu granic czasowych mocy obowiązującej ustawy o kompromisach ${ }^{36}$. W tym miejscu należy wyjaśnić, że do XVIII w. w Koronie funkcjonowanie sądów polubownych oparte było na prawie zwyczajowym ${ }^{37}$. W 1726 r. uchwalono dla prowincji Wielkiego Księstwa Litewskiego - gwarantującą nienaruszalność kompromisów - konstytucję sejmową „Obwarowanie sądów polubownych alias kompromisarskich” ${ }^{\text {, }}$, która w roku 1776 rozciągnięta została na Koronę ${ }^{39}$ ustawą „Deklaracja o komisjach i remissach z przeszłego sejmu wypadłych" ${ }^{40}$. Pojawił się wówczas problem mocy wiążącej konstytucji. Sąd ziemski czerski zapytał Radę o dopuszczalność stosowania ustawy o kompromisach w odniesieniu do tych umów na sąd polubowny, które zawarto przed 1776 r. Hołdując zasadzie o niedziałaniu prawa wstecz, konsyliarze orzekli: ,że gdy prawo Wielkiego Księstwa Litewskiego o kompromisach napisane, na Koronę rozciągnione, inskrypcyi kompromisarskiej nie uprzedziło, lecz następnie wypadło, ściągać się zatym do poprzedzających inskrypcyi nie może"41. Niestety z treści rezolucji nie wynika, jakie były okoliczności przedłożenia Radzie powyższego pytania. Nie

${ }^{36}$ Szerzej o problematyce obowiązywania prawa w czasie: H. Grajewski, Granice czasowe mocy obowiazującej norm dawnego prawa polskiego, Łódź 1970.

${ }^{37}$ Kwestię sadów polubownych regulował natomiast obowiązujący na Litwie III Statut. Poświęcony im art. 85, rozdz. IV dopuszczał w razie odmowy wykonania wyroku sądu polubownego przez stronę sporu złożenie przypozwu przez stronę przeciwną do sądu ziemskiego, który po rozpoznaniu kompromisu i stwierdzeniu jego zgodności z prawem miał go „przy mocy zachować i odprawę według tego sądu czynić". Podobnie w przypadku dekretu rozpisowego sądu polubownego Statut umożliwiał przekazania przez strony sprawy do ziemstwa, w celu rozstrzygnięcia, który z arbitrów kompromisu wydał wyrok zgodnie z obowiązującym prawem, a tym samym który „,sąd przy mocy zostawić". Warto również wspomnieć, że możliwość jednania przewidywał art. 25 rozdz. IV Statutu, Statut Wielkiego Księstwa Litewskiego (...) teraz zaś za Naijaśniejszego Króla Stanisława Augusta (...) przedrukowany, Wilno 1786. Na uwagę zasługuje fakt, że pomimo uchylenia III Statutu Litewskiego w guberniach zachodnich Cesarstwa Rosyjskiego w 1840 r., jego przepisy dotyczące sądownictwa polubownego stosowano jeszcze w latach następnych, co thumaczyć można przywiązaniem szlachty do rodzimych rozwiązań prawnych, S. Godek, III Statut Litewski w dobie porozbiorowej, Warszawa 2012, s. 191-192.

${ }^{38}$ VL VI, fol. 490-491. Jak wyjaśniał ustawodawca, potrzeba uchwalenia wspomnianej konstytucji pojawiła się w związku z praktyką zrywania kompromisów przez zapisane na nie strony i często odnotowywanymi przypadkami braku jednomyślności arbitrów tworzących sąd polubowny. W konsekwencji zamiast usprawnienia i przyspieszenia, rozstrzyganie sporów w drodze postępowania polubownego przeciągało się w czasie. Zapobiegając takiemu stanowi rzeczy konstytucja nakazała stronom przestrzeganie zapisów kompromisarskich, m.in. przez kończenie spraw w tych sądach polubownych, w których zostały rozpoczęte. Zastrzeżono również zakaz odwoływania się od wyroków sądów polubownych do jakichkolwiek majoris et minoris subsellij, a w przypadkach dekretów rozpisowych arbitrów kompetencję do rozstrzygania sporu przekazywano Trybunałowi W. X. L.

39 Być możena tej podstawie T. Ostrowski sformułował swoją błędną tezę o pojawieniu się sądów polubownych w Koronie dopiero w 1776 r. zob. przypis nr 3.

${ }^{40}$ VL VIII, fol. 879.

${ }^{41}$ Rezolucja nr 347 z 3.10.1777 r., Zbiór rezolucyi Rady Nieustajacej, Warszawa 1785, s. 93. 
wiemy także, kto i z jakiej przyczyny był bezpośrednio zainteresowany rozstrzygnięciem tej kwestii. $Z$ wyjaśnień konsyliarzy wynika jedynie, że w razie wątpliwości lub sporów dotyczących umów na sąd polubowny zawartych przed 1776 r. nie można było powoływać się na obowiązującą konstytucję sejmową. Jednocześnie, co ważne, nie wspomniano o nieważności takich zapisów, co w przypadku ich naruszenia przez jedną ze stron w dalszym ciągu mogło stanowić podstawę do skierowania sprawy do sądu ziemskiego za złamanie umowy.

W przesyłanych do Rady memoriałach kilka razy poruszono także kwestię dotyczącą uczestników postępowania, zarówno stron toczącego się sporu, jak i sędziów polubownych. Przykładem jest skierowany do Rady memoriał pisarza ziemskiego wołkowyskiego, Michała Bułharyna. W podnoszonym przez niego przypadku wątpliwości dotyczyły kręgu podmiotów uprawnionych do zawierania umów na sąd polubowny - osób stanu duchownego. Punktem wyjścia było, zdaniem Bułharyna, ustalenie, czy „,dobra funduszowe, a corpore bądź królewskich, bądź szlacheckich, bądź miejskich majątków wyjęte, tracą początkową swoją naturę i dziedzictwem jakoby kościelnym stają się", a co za tym idzie - wskazanie uprawnień przedstawicieli duchowieństwa, którzy dożywotnio użytkując majątek kościelny, mają zakaz działania ,ze szkodą in proprietate, czyli to haereditatis Ecclesiae". Zapytał więc, po pierwsze: czy „osoba duchowna, dobra kościelne dzierżąca, może ugody zawierać?”, po drugie: czy „do kompromisów [może] pisać się sama, czyli pod powagą starszeństwa, a w przypadku, iżby interwencja onego koniecznie potrzebną była: jaka i jak zupełną ta być powinna?". Rada orzekła, iż dobra przekazane kościołowi należy traktować „za wyjęte spod dawnej natury i za własność kościelną [mają być] poczytane dotąd, pokąd Rzeczpospolita na sejmach, co jasnego lub szczególnego, z najwyższej mocy swej nie postanowi”. Jednocześnie zakończyła wywód stwierdzeniem, że ,sprawiedliwość równoważna, nie dozwala bynajmniej tego, aby dobrodziejstwo w kompromisach, służyć nie miało osobom duchownym, podobnie jako i świeckim, przeto nie inaczej, jak w asystencyi delegowanego ab officio, qua plenipotenta, dobranych a loci ordinario kompromisarzów i z zachowaniem wszelkich formalności, z prawa duchownego nakazanych, in objecto alienationis bonorum, może beneficiatus ksiądz, na polubowny sąd opisywać się"42. Rada potwierdziła zatem, że mimo szczególnego charakteru własności kościelnej osoby duchowne mogą korzystać z sądów polubownych na takich samych zasadach, jak przedstawiciele pozostałych stanów ${ }^{43}$.

Jak wspomniano, wątpliwości budził również problem arbitrów, w szczególności reguł ich obsadzania, o czym świadczy m.in. memoriał przesła-

${ }^{42}$ Rezolucja nr 341 z 30.5.1786 r., Zbiór rezolucyi..., 1788, s. 138.

${ }^{43}$ Znane są również przypadki korzystania z kompromisów przez siostry zakonne, A. Rosner, Tradycja..., s. 43. 
ny przez stolnika podlaskiego Franciszka Kuszla. Przywołując konstytucję z 1726 r. „Trybunał Główny Koronny”, zakazującą sędziom Trybunału „wchodzenia w kompromisy stante functione sub nullitate judicati”44, Kuszel, interpretując zresztą ów przepis jako dotyczący jedynie superarbitrów, zapytał, czy deputat wybrany na arbitra jeszcze przed objęciem funkcji w Trybunale, rozpocząwszy już procedurę polubowną, może, po przeprowadzeniu m.in. przesłuchania jednej ze stron i części świadków, wraz z superarbitrem dokończyć dzieło sądu polubownego, pełniąc równocześnie urząd deputata. Rada Nieustająca odrzuciła taką interpretację, zaznaczając, że „deputatowi w każdym czasie funkcyi swojej, aż do jej zakończenia, innymi sądami, oprócz trybunalskich, zatrudniać się nie dozwala", podkreślając jednocześnie, iż w przypadku podjęcia przez niego czynności w sądzie kompromisarskim „akty takowe (choćby przez strony przyjęte były) niszczy, tak też i sądów polubownych, stante eadem Tribunalitia functione, deputatom kontynuować nie daje mocy"45. Rezolucja Rady w sposób definitywny rozstrzygnęła więc problem uczestnictwa członków Trybunału w czynnościach sądów kompromisarskich. Rozwiązanie to miało zapobiegać zjawisku nagminnego opuszczania przez deputatów posiedzeń Trybunału ${ }^{46}$, a przez to zapewnić mu większą sprawność działania. I choć przyczyn sędziowskich absencji zapewne można upatrywać także w braku dyscypliny lub wręcz niechęci szlachty do trudnej i wymagającej pracy deputata, to jednoznaczne potwierdzenie przez Radę ustawowego zakazu uczestnictwa w kompromisach miało skłonić deputatów do koncentrowania się w głównej mierze na obowiązkach w Trybunale.

Innego rodzaju przypadek opisał w swoim memoriale pełniący funkcję superarbitra podkomorzy płocki - Gabriel Karwosiecki ${ }^{47}$. Zgłoszone przez niego wątpliwości dotyczyły interpretacji reguły ustanowionej w zapisie na kompromis, pozwalającej sądowi polubownemu wydać wyrok po odstąpieniu lub pod nieobecność jednej ze stron. Zasada ta nie przewidywała jednak sposobu postępowania w sytuacji, gdy, jak to podnosił Karwosiecki: „strona odstępując od sądu razem i od siebie mającego wolność stawić się do sądu arbitra, odciąga i nie stawi”. Rodziło się zatem pytanie: „czy może superarbiter sam z drugim arbitrem sąd rozpoczynać i kończyć, albo nie?”. Rada Nieustająca wyjaśniła, że decydująca w tym zakresie była treść zawartego przez strony kompromisu. W przypadku wskazania w zapisie - obok osoby superarbitra - arbitrów wymienionych z imienia i nazwiska, do wydania wyroku wymagany był pełen skład sądu, co można poczytywać jako zabezpieczenie strony przed rozstrzygnięciem dokonanym przez sąd bez udziału jej arbitra,

44 VL VI, fol. 423.

45 Rezolucja nr 400 z 9.7.1784 r., Zbiór rezolucyi..., 1786, s. 34.

46 Zob. więcej: W. Bednaruk, Trybunat Koronny..., s. 274.

47 Zob. więcej: K. Zienkowska, Karwosiecki Gabriel Antoni, PSB, t. XII, Kraków 1966-67, s. 158. 
na wypadek jego nieobecności na sprawie. Natomiast w razie powołania wyłącznie superarbitra, gdy „dodanie arbitrów stronom jest zostawione, bez specyfikacyi osób, lecz kogo się im zdarzy uprosić i do sądu zasadzić, na ów czas umknienie arbitra i niestawienie się jego do sądu, nie inaczej, jako za odstąpienie samej strony ma być rozumiane, zostawując superarbitrowi poczynania według reguły zapisanej na kompromis"48. Zdaniem Rady, niewskazanie przez stronę w umowie konkretnej osoby na funkcję arbitra skutkowało tym, że w przypadku niestawienia się owego arbitra na sądzie kompromisarskim superarbiter mógł bez przeszkód kontynuować procedurę polubowną. Jednocześnie podkreślono, że powyższa sytuacja wywoła takie same skutki jak odstąpienie strony od kompromisu, co - jak wiadomo - nie było dopuszczalne. Jakie było ratio legis takiego rozstrzygnięcia? Wydaje się, że przyjęta interpretacja miała sprzyjać sprawnemu działaniu sądów polubownych i zapobieganiu sytuacjom, w których praca sądu mogła być - w razie odstępowania od kompromisu lub absencji na zjeździe stron i ich arbitrów - paraliżowana lub opóźniana.

Zgłaszający się do Rady Nieustającej sygnalizowali także pewne wątpliwości dotyczące kompetencji sądów polubownych, w tym rodzaju spraw, które można było im powierzyć do rozstrzygnięcia. Obiekcje takie przedstawił w swoim memoriale wspomniany już Franciszek Kuszel. Mając na uwadze treść konstytucji „Deklaracja o komisjach i remissach” z 1776 r., rozciągającej na Koronę prawo przyjęte w 1726 r. dla Wielkiego Księstwa Litewskiego, zasugerował, że ustawa ta „zdaje się tylko pozwalać zapisywania kompromisu w sprawach tych, które były komisjami sejmu 1775 roku objęte". Chcąc wyjaśnić tę kwestię, zapytał: „czyli więc toż prawo, daje moc zapisywania kompromisów we wszelkich sprawach ziemskich? I jakie mają być sprawy, rozumiane za ziemskie?". Rada odrzuciła interpretację przedstawioną przez Kuszla, wyjaśniając, że konstytucja z 1726 r. „we wszelkich sprawach zapisywania sądu polubownego dozwala. Prawo zaś 1776 mówiąc o kompromisie, sprawy ziemskie wymienia, przeto podług obmowy tych praw obydwóch, wszelkie sprawy ziemskie pod rozsądzenie kompromisów podpadać mogą"49.

Problem uprawnień przysługujących sądom polubownym poruszył komornik ziemski radomski, Franciszek Strzałkowski. Zapytanie odnosiło się do kwestii proceduralnej i dotyczyło zwoływania przez sąd kompromisarski kondescensji, a więc zjazdu sądu na sporny grunt. Strzałkowski zapytał: „gdy w zapisie kompromisarskim nie ma nadanej wyraźnie sądowi polubownemu mocy wyznaczania kondescensyi sądów ziemskich lub grodzkich urzędów, czy może tenże sąd polubowny albo od siebie wyznaczyć kondescensję, albo stronie zalecić wprowadzenie urzędnika do egzekucyi jego dekretu? I czyli akt

\footnotetext{
${ }^{48}$ Rezolucja nr 375 z 18.6.1784 r, Zbiór rezolucyi..., 1786, s. 34.

${ }^{49}$ Rezolucja nr 400 z 9.7.1784 r., Zbiór rezolucyi..., 1786, s. 34.
} 
urzędnika sprowadzonego w tym przypadku, może być rozumiany za legalny, mający tęż samą powagę, co sąd kompromisarski?’" Rada odpowiedziała, że decydująca $\mathrm{w}$ tym zakresie jest reguła przewidziana w zapisie na kompromis, ale jednocześnie stanowczo zaznaczyła: „Żeby zaś sąd kompromisarski mógł arbitralnie urzędy ziemskie lub grodzkie na kondescensje powagą wyroku swego zsyłać, żadnym prawem o kompromisach pisanym nie jest do tego umocowanym". Według konsyliarzy urzędy ziemskie i grodzkie miały prawo wyznaczania kondescencji tylko w przypadku, gdy „,z obopólnej stron umowy zapisem kompromisarskim pozwolonej tej mocy udział mają sobie wyraźnie dany”. Na pytanie o prowadzenie egzekucji wyroków sądów polubownych Rada oznajmiła, iż ,dekreta kompromisarskie jako są dekretami ostatecznymi, tak do egzekucyi przez sąd każdy doprowadzone być powinny"50.

Skomplikowane i wielopłaszczyznowe spory między skonfliktowanymi stronami prowadziły do praktyk polegających na „wciąganiu” pod rozstrzygnięcie sądu polubownego także tych spraw, które nie zostały wyszczególnione w zapisie na kompromis. Materii tej poświęcił swój memoriał Władysław Ciołkowski, sędzia grodzki stężycki, który zapytał, jak postępować w przypadku, gdy sąd polubowny „sprawę pod zapis niepoddaną, owszem wcale wyjętą, przez decyzję swą zajął?”. I dodał: „czyli ukrzywdzonemu w takim przypadku naprzeciwko dekretowi polubownemu, czynić się godzi, i gdzie?”. Podjęty został w tym miejscu nie tylko problem uprawnień sądu kompromisarskiego, ale także postępowania stron $\mathrm{w}$ odniesieniu do wydanego $\mathrm{w}$ takim przypadku wyroku. Autorzy rezolucji odpowiedzieli Ciołkowskiemu, że „,w kategoryi nieprzyzwoicie i nienależnie $\mathrm{w}$ sąd polubowny wciągnionej i rozsądzonej strony czynić mogą in foro gatunkowi sprawy competenti" ${ }^{51}$. Konsyliarze stwierdzili zatem, że strony kompromisu mają prawo udać się w sprawie, którą, przekraczając swoje kompetencje, rozstrzygnął sąd polubowny, do sądu właściwego przedmiotowo. Rada nie wypowiedziała się natomiast, czy wyrok kompromisarski wydany w zakresie nieprzewidzianej w umowie materii pozostawał w mocy czy podlegał procedurze unieważnienia.

Innego rodzaju problem podniesiono w rezolucji stanowiącej odpowiedź na memoriał ziemstwa kaliskiego. Dotyczył on wpisywania umowy powołującej do życia sąd polubowny do akt urzędowych. Jak wynika z doniesienia sądu, sporządzony między członkami rodziny Trembińskich zapis na kompromis nie został zeznany przed aktami publicznymi, a i sam sąd nie doszedł do skutku w planowanym terminie. W rezultacie jedna ze stron sporu zażądała realizacji zapisu i zwołania kompromisu zgodnie z treścią umowy, druga, podnosząc zarzut niedopełnienia prawa, wniosła o uznanie jej za nieważną. W odpowiedzi na wątpliwości kaliskich sędziów, Rada Nieustająca przywołała

\footnotetext{
${ }^{50}$ Rezolucja nr 257 z 29.4.1788 r., Zbiór rezolucji..., 2014, s. 270.

${ }^{51}$ Rezolucja nr 149 z 19.8.1785 r., Zbiór rezolucyi..., 1788, s. 68.
} 
fragment konstytucji z 1726 r. stanowiący, że ,in futurum wszelkie sprawy na kompromis przez strony sponte zapisem in quoqunque subsellio przyznanym ordynowane etc.", i zwracając szczególną uwagę na zwrot in quoqunque subsellio, potwierdziła nakaz rejestrowania zapisów na kompromis w którymkolwiek urzędzie, co było warunkiem nadania owemu zapisowi mocy prawnej ${ }^{52}$.

Prorogacji, a więc odłożeniu terminu rozpoczęcia sądu polubownego, Rada poświęciła jedną rezolucję wydaną na wniosek wspomnianego wyżej sędziego grodzkiego Władysława Ciołkowskiego. Zapytał on, prawdopodobnie w związku z próbą odroczenia przez jedną ze stron kompromisu terminu wszczęcia pracy przez sąd, ,czyli prorogacja sądu kompromisarskiego jednostronna, opisem kompromisu całemu nawet sądowi niedozwolona jest tak prawną, aby drugą stronę na tę prorogację niedozwalającą, do sądzenia się obowiązywać mogła lub nie?’. Rada wyjaśniła, że podstawą działania jest w takim przypadku umowa stron, a sąd ,podług inskrypcyi quo ad literam zachować się ma", co należy tłumaczyć jako ciążący na stronach i arbitrach obowiązek rozpoczęcia obrad sądu w terminie wskazanym w zapisie na kompromis. Równocześnie jednak stwierdzono, iż ,gdy czas praefixe do rozsądzenia jest wyznaczony, po upłynieniu onego bezczynnym, powaga sądu ustawać powinna" ${ }^{53}$, dając tym samym do zrozumienia, że nieprzystąpienie uczestników kompromisu do procedury polubownej we wskazanym czasie oznacza utratę przez sąd nadanych mu kompetencji.

W przedłożonych Radzie memoriałach poruszano również kwestię odsyłania spraw z sądów polubownych do sądów państwowych.

O możliwość taką zapytali sędziowie ziemstwa żytomierskiego. W opisywanym przez nich przypadku strony toczące ze sobą spór w sądzie ziemskim, w którym zapadł dekret nakazujący pozwanemu odprzysiężenie się z postawionych mu zarzutów, doszły do porozumienia w kwestii przekazania wszystkich rozpoczętych między nimi spraw sądowi kompromisarskiemu. Gdy po kilku latach przeciągającego się postępowania polubownego kompromis upadł, strona powodowa zdecydowała o ponownym przekazaniu sprawy sądowi ziemskiemu, żądając od pozwanego zadośćuczynienia wcześniej wydanemu w tym ziemstwie dekretowi. Ten, powołując się w sądzie ziemskim na postanowienia konstytucji sejmowych i przedkładając umowę powołującą w przedmiotowej sprawie sąd polubowny, odmówił. Sąd żytomierski zwrócił się wówczas z pytaniem do Rady Nieustającej: „Czyli tedy po upadłym terminie kompromisu, sprawy pod tenże kompromis poddane, wrócić się mają do tych jurysdykcyi gdzie zaczęte były? Czyli za podniesieniem od superarbitra kompromisu w tym sądzie gdzie terminowane i kończone finaliter być powinny?”. Powołując się na treść ustawy z 1726 r., Rada oświadczyła, ,iż

\footnotetext{
52 Rezolucja nr 261 z 6.5.1788 r., Zbiór rezolucji..., 2014, s. 274.

53 Rezolucja nr 149 z 19.8.1785 r., Zbiór rezolucyi..., 1788, s. 68.
} 
gdzieby po upadłym terminie nie był ostrzeżony upad kompromisu, tam strony za podniesieniem drugiego terminu, nie gdzie indziej, tylko w sądzie kompromisarskim rozpierać się powinny" ${ }^{54}$. Zatem konsekwentnie trzymając się litery prawa ustanowionego we wspomnianej konstytucji, nakazującego bezwzględnie kończyć w sądzie polubownym wszystkie spory w nim rozpoczęte, Rada zanegowała możliwość ponownego skierowania rzeczonej sprawy pod rozstrzygnięcie sądu ziemskiego.

W podobnej sprawie pełniący funkcję arbitra w sądzie polubownym Jan Kanty Karwosiecki ${ }^{55}$ zapytał, czy w przypadku wspólnej decyzji arbitrów i superarbitra o odesłaniu sprawy spornej - już po jej rozpoznaniu - ubi de jure, sąd polubowny ma obowiązek na żądanie od którejkolwiek strony ,podnieść termin kompromisu i sprawę finalnie według zapisu kompromisyjnego rozsądzić?". Rada, odwołując się do postanowień poświęconego sądom polubownym uniwersału ${ }^{56}$ z $1786 \mathrm{r}^{57}$, zaznaczyła, , iż na fundamencie kompromisarskiego obustronnego zapisu, superarbiter i arbitrowie sprowadzeni, jurysdykcję sądów swoich ufundować, accesoria in forma judiciorum ułatwić, indukt wysłuchać, a na koniec po odeszłych replikach ostatnią decyzję ferować i sentencję deklarować powinni" 58 . W sposób niebudzący wątpliwości potwierdziła więc obowiązek sądu polubownego do zakończenia postępowania polubownego wydaniem wyroku końcowego.

Wkrótce jednak rezolucja ta stała się przedmiotem memoriału autorstwa jednego z członków Rady - Romualda Walewskiego ${ }^{59}$, który sugerując wady takiego rozstrzygnięcia (wskazując na ryzyko kolizji w jurysdykcjach) zapytał: czy w sytuacji, gdy sąd polubowny ,zamiast finalnego dekretu ferowania, sprawę całą ad quem de jure odesłał, (...) strony conformiter wydały termina do sądu sprawie przyzwoitego, superarbiter może być następnie zmuszony przeciwko własnej sentencyi, na nowo zasiadać i sądzić, bez nowego na to polubownego od stron jego na superarbitra zapisania?", co więcej - pytał dalej konsyliarz - czy „strona może przymuszać drugą stronę do powtórzenia takowego zapisu, który w takowym razie jużby przestał być polubownym?". Rada Nieustająca przypomniała, ponownie przywołując w odpowiedzi zarówno konstytucje sejmowe z 1726 i 1776 r., jak i treść swojej poprzedniej rezolucji, że sprawy rozpoczęte $\mathrm{w}$ sądzie polubownym winny być $\mathrm{w}$ nim za-

54 Rezolucja nr 192 z 2.9.1783 r., Zbiór rezolucyi..., 1786, s. 32.

55 Karwosiecki Jan Kanty h. Lubicz - łowczy chęciński (1784-1794), komornik graniczny (1785), Urzędnicy województwa sandomierskiego XV-XVIII wieku. Spisy, red. A. Gąsiorowski, oprac. K. Chłapowski, A. Falniowska-Gradowska, Kórnik 1993, s. 184.

${ }^{56}$ Uniwersały były przepisami o charakterze normatywnym. Wychodziły jako akta królewskie, ogłaszane za zdaniem Rady Nieustającej, S. Kutrzeba, Historia źródel dawnego prawa polskiego, t. I, Lwów 1925, s. 203.

57 Zob.: Uniwersał nr 305, Zbiór rezolucyi..., 1788, s. 164.

58 Rezolucja nr 119 z 1.6.1787 r., Zbiór rezolucji..., 2014, s. 137.

59 Zob. więcej: A. Czaja, Między tronem..., s. 92. 
kończone. Dodała, ,że superarbiter z obowiązku przyjętego, na siebie dobrowolnie urzędu, sądzenia kompromisu, nie mógł był i nie powinien, od tego sądu supersesyi czynić, ale onże finalnie kończyć". Podkreślono niebezpieczeństwo wynikające z odsyłania stron do innego sądu, co mogło podważyć zaufanie do instytucji kompromisów i wystawić na „niepewność tej spokojności, którą prawa zabezpieczyły, a którą sobie strony wzajemnie w dobrej wierze i ufności superarbitra i z nim wybranych arbitrów do sądu zasadzając, na zawsze zamierzyły”. Dlatego na zakończenie Rada zaznaczyła: „przeto jako superarbiter wszystkie strony od sądu swego odsyłając ubi de jure oddalił, tak gdy od tychże stron wszystkich w zapis kompromisarski wchodzących rekwirowany będzie, winien jest sąd swój podnieść i tymże stronom finalną wymierzyć sprawiedliwość" 60 .

Stosunkowo dużo uwagi w nadesłanych memoriałach poświęcano kwestii samych wyroków sądów polubownych.

Na początek przyjrzyjmy się rezolucjom Rady poświęconym szeroko rozumianej problematyce wpływu dekretów sądów kompromisarskich na osoby trzecie, które nie występowały jako strona postępowania polubownego. Zagadnienie to było przedmiotem memoriału skierowanego do Rady przez sędziego Władysława Ciołkowskiego z grodu stężyckiego, który zapytał czy „osoby do jedności interesu należące, a do sądu polubownego niepiszące się, na przykład siostry i inni sukcesorowie, ulegać mają decyzyi sądu polubownego?". Zasygnalizowany przez Ciołkowskiego problem miał zapewne powszechny charakter, częstym zjawiskiem - jak można przypuszczać - była bowiem sytuacja, gdy w toczący się spór, przynajmniej po jednej ze stron, zaangażowane było więcej osób, względnie gdy rozstrzygnięcie sporu mogło wywołać skutki prawne także w odniesieniu do tych z nich, które umowy na kompromis nie zawierały. Odpowiedź Rady miała więc istotne znaczenie dla wszystkich zainteresowanych w sprawie, lecz niekoniecznie bezpośrednio biorących udział w postępowaniu polubownym. Wedle wyjaśnień konsyliarzy, zgodnie z generalną zasadą, „kompromisa nie mogą inne osoby w inskrypcję niewchodzące pod sąd swój do przyjęcia decyzyi pociągać”. Równocześnie Rada podkreśliła, że ,gdyby jednak przypadkiem podciągnięte [inne osoby], wyrok ten za legalny przyjęły i onemu we wszystkim zadosyć uczyniły, takowy dekret, ważnym i niewzruszonym być powinien" ${ }^{61}$. Rezolucja ta zatem zabezpieczała na wypadek niekorzystnego dla nich rozstrzygnięcia osoby, które do sądu polubownego nie przystąpiły, a jednocześnie stanowiła, że w razie satysfakcji z wyroku i jego akceptacji przez wszystkich zainteresowanych w sprawie, nabierał on mocy wiążącej, co dawało szansę na ostateczne zakończenie sporu.

${ }^{60}$ Rezolucja nr 180 z 23.11 .1787 r., Zbiór rezolucji..., 2014, s. 185.
${ }_{61}$ Rezolucja nr 149 z 19.8.1785 r., Zbiór rezolucyi..., 1788, s. 68. 
Swoje stanowisko w tej kwestii konsyliarze podtrzymali w jednej z kolejnych rezolucji, kiedy do Rady Nieustającej wpłynął memoriał, w którym generał Jan Aleksander Kraszewski ${ }^{62}$ prosił o wyjaśnienie „czy nowy dziedzic, kupiwszy wieś, może być przymuszonym od sądu, trzymać i kończyć kompromis, przez dawniejszego dziedzica zapisany i zaczęty, ale kilkokrotnymi limitami, przez więcej dwuletni przeciąg zwlekany i nieskończony?”. W dalszej części Kraszewski pytał o możliwość wstąpienia przez nabywcę nieruchomości na „ordynaryjną”, co tłumaczyć należy - urzędową „prawa drogę”. Również opisany tu przypadek prawdopodobnie nie należał do rzadkości, co tym bardziej wpływało na potrzebę wydania w tym zakresie rezolucji. I tak Rada stwierdziła w odpowiedzi, ,iż inskrypcje sądu kompromisarskiego wiążą te osoby, które się nań sponte zapisały: zaczym, jeżeli nowy dziedzic wsi w memoriale wzmiankowany, w tranzakcyi rezygnacyjnej przez porządniczego tejże wsi dziedzica, nie ma ostrzeżonego ukończenia, rozpoczętego in ante kompromisu, inskrypcja na tenże kompromis poprzednicza, wiązać go nie może"63. Decydujące znaczenie miała więc w tym i podobnych przypadkach treść umowy zbycia nieruchomości i ewentualne umieszczenie w niej warunku kontynuowania sądu polubownego przez następcę prawnego. Brak takiego zastrzeżenia z obowiązku tego go zwalniał.

Omawiany problem wrócił na plenum Rady w roku kolejnym, kiedy z żądaniem uchylenia dekretu sądu polubownego przez ziemstwo krzemienieckie zwrócił się do konsyliarzy Stanisław Batkowski, współdziedzic majątku Batkowo i Leduchowo, którego bracia w drodze zawartego - bez jego udziału - kompromisu, podzielili nieruchomość między siebie. Rada powołała się w rezolucji na konstytucję z 1784 r. pt. „Illegalność procesu” przypominając, że nie są zgodne z prawem procesy, ,którymi strona, sądem polubownym (w zapis onego niewchodząca) zajęta była". Dlatego, jak dalej wytłumaczono, „sąd, do którego kognicyi takowa sprawa wytoczy się, jeżeli strona okaże, że w zapis kompromisarski nie wchodziła, podług wyżej rzeczonego prawa, sprawiedliwość jej wymierzy"64. Rada Nieustająca, opierając swoje stanowisko na obowiązującej ustawie, przychyliła się więc do wniosku Batkowskiego. Dodać jedynie wypada, że rezolucja ta w pełni zresztą wpisywała się w jej dotychczasowe orzecznictwo w tym zakresie.

O powszechnym charakterze poruszanego problemu niech poświadczy jeszcze jedna rezolucja. Sprawa przedłożona przez Departament Wojskowy Rady dotyczyła sporu granicznego między Franciszkiem Czackim, strażnikiem

62 Kraszewski Jan Aleksander - generał major wojsk koronnych (1775-1787), Oficerowie Rzeczypospolitej Obojga Narodów 1777-1794. Spisy, t. I, cz. 1: M. Machynia, C. Srzednicki, Wojsko Koronne. Sztaby i kawaleria, Kraków 2002, s. 129.

63 Rezolucja nr 191 z 25.10.1785 r., Zbiór rezolucyi..., 1788, s. 69.

64 Rezolucja nr 261 z 3.1.1786 r., Zbiór rezolucyi..., 1788, s. 70. 
wielkim koronnym ${ }^{65}$, a szambelanem królewskim, Michałem Urbanowskim. Obaj zdecydowali o przekazaniu sporu pod rozstrzygnięcie sądu polubownego, ale jak wynika z treści rezolucji zapis na kompromis ,żadnej o sukcesorach wzmianki, iżby ci w przypadku śmierci strony piszącej się do tego sądu [polubownego] ciągnieni być mogli”. Już po rozpoczęciu procedury i wydaniu przez sąd kompromisarski kilku dekretów akcesoryjnych, Franciszek Czacki zmarł, pozostawiając wdowę z nieletnimi dziećmi. Szambelan Urbanowski odmówił kontynuowania sądu polubownego, uznając, ,iż kompromis niebywszy za życia strony jednej nań piszącej się uskutecznionym, upadł", a dodatkowo podniósł argument, ,że sąd nie mógłby w nieletniości dziedzica sprawy granicznej sądzić, a to według praw koronnych i Statutu W. X. L. województwu wołyńskiemu służącego". Wkrótce zmarł również Michał Urbanowski. Kiedy sąd kompromisarski zadekretował przekazanie sprawy do właściwego sądu podkomorskiego w celu poprowadzenia duktów i usypania kopców na spornym gruncie, a ten podjął $\mathrm{w}$ tym zakresie stosowne działania, opiekunowie nieletniego spadkobiercy Urbanowskiego zablokowali czynności urzędników granicznych podnosząc, ,iż kompromis za życia nań [stron] piszących się, wyroku sprawę rozsądzającego niemający wiązać sukcesorów nie powinien, iż sprawa graniczna między małoletnimi dóbr dziedzicami sądzoną być nie może". W odpowiedzi Czaccy złożyli wniosek do Rady Nieustającej o przydzieleniu pomocy wojskowej w celu wykonania wyroku sądu polubownego. Konsyliarze, przywołując w rezolucji wspominaną już konstytucję z 1726 r., stwierdzili, „iż kompromisa inter personas paciscentes sponte ex consensu ambarum partium zapisane, koniec i egzkucję swoją brać powinny, ex quo żadne subsellium by najwyższe w rozeznawanie spraw sądom polubownym oddanych wchodzić, a tym bardziej unikczemniać kompromisu nie mają mocy”. Równocześnie, biorąc pod uwagę statuty Kazimierza Wielkiego oraz Statut Litewski chroniące małoletnich przed niekorzystnym rozporządzeniem ich majątkiem przez opiekunów, a w szczególności zakazujące „utracać” go lub „graniczyć”, Rada odmówiła przydzielenia pomocy wojskowej przeciwko nieletniemu Urbanowskiemu. Rezolucję zakończono słowami: „Za dojściem zaś do lat ciż sukcesorowie będą wiedzieli, jak w mocy aktorstwa i w sile praw tak o kompromisach, jako i o bezpieczeństwie minorennium stanowionych wzwyż wycytowanych, będą mogli w czasie dysponować się względem kompromisu między ojcami nastałego, a niespodzianą ichże śmiercią nieskończonego" ${ }^{66}$. Sprawa ulec więc miała zawieszeniu, Rada pozostawiła jednak małoletnim następcom prawnym stron, które zawarły umowę na sąd polubowny

65 Czacki Franciszek h. Świnka - strażnik wielki koronny (1766-1787), Urzędnicy centralni i nadworni Polski XIV-XVIII wieku. Spisy, red. A. Gąsiorowski, oprac. K. Chłapowski, S. Ciara, Ł. Kądziela, T. Nowakowski, E. Opaliński, G. Rutkowska, T. Zielińska, Kórnik 1992, s. 162.

66 Rezolucja nr 199 z 21.12.1787 r., Zbiór rezolucji..., 2014, s. 211. 
- po osiągnięciu przez nich pełnoletności - możliwość wyboru drogi prawnej kończącej rozpoczęty jeszcze za życia ich ojców spór graniczny.

$\mathrm{W}$ odniesieniu do wyroków problemem mogło być tzw. rozpisanie sentencji - sytuacja, w której rozbieżność zdań wśród tworzących skład arbitrów uniemożliwiała wydanie jednomyślnego dekretu rozstrzygającego rozpoznawany spór.

Przypadek taki opisał w nadesłanym raporcie sąd ziemski żytomierski. Jak wynika z treści rezolucji, po wydaniu wyroku ${ }^{67}$ przez sąd polubowny jedna ze stron kompromisu, opierając się na korzystnej dla niej sentencji superarbitra i powołanych przez nią arbitrów, zdecydowana była kontynuować proces, druga - niepopierająca dekretu, powołała się na Statut Litewski ${ }^{68}$ i zwróciła do sądu ziemskiego, wnosząc o jego uchylenie. Strona podtrzymująca chęć utrzymania kompromisu, nie uznała jednak forum wspomnianego ziemstwa, thumacząc, że na mocy uchwalonej dla Wielkiego Księstwa Litewskiego konstytucji z 1726 r. - rozciągniętej w roku 1776 na Koronę - sentencje rozpisowe winien rozpoznawać Trybunał. Wobec obiekcji sądu ziemskiego, Rada Nieustająca podkreśliła, że „późniejsze prawa są pierwszych związaniem” i uznała - w obliczu kolizji dwóch wspomnianych aktów - pierwszeństwo ustawy z 1726 r. przed Statutem Litewskim. Wątpliwości sędziów żytomierskich starała się równocześnie rozjaśnić w słowach: ,gdzieby w rozróżnienie sędziów kompromisarskich palpabilis pluralitas nie znajdowała się, poznanie takowego rozróżnienia i decyzję, nie ziemstwom, ale Trybunałom poleca"69.

W rezolucjach poświęconych sądom kompromisarskim pojawił się również problem apelacji od wyroków polubownych. Wspomniany już wcześniej Władysław Ciołkowski z grodu stężyckiego, mając na uwadze konstytucję z 1726 r. wprowadzającą generalny zakaz odwoływania się od wyroków sądów polubownych (in semota appellatione), zwrócił się do Rady z zapytaniem o dopuszczalność apelacji w przypadku, gdy w opisie kompromisu warunek inappellabilitatis nie został wyrażony expressis verbis. Rada wyjaśniła w odpowiedzi, że „konstytucja z 1726 r. (...) przepisując w kompromisach aryngę mającą się wyrażać «semota appellatione» nie znosi tym samym ważności dekretów, które pro inappellabilibus są tymże prawem przyznane"70. Jak należy rozumieć te słowa? W myśl zajętego przez konsyliarzy stanowiska brak warunku o niedopuszczalności apelacji w umowie na kompromis nie oznaczał, że możliwość odwołania się od wyroku sądu polubownego istniała. Stwierdzono, że dekrety sądu kompromisarskiego pozostają „ważne”, a więc

${ }^{67} \mathrm{~W}$ rezolucji nie wspomniano, czy był to wyrok stanowczy czy akcesoryjny.

${ }^{68}$ Chodziło o wspomniany już artykuł 85 rozdziału IV Statutu z 1588 r., w myśl którego: „A gdzieby się sąd polubowny pokazał różny, o takowy sąd gdy się obie stronie przed urząd ziemski przypozwą".

${ }^{69}$ Rezolucja nr 254 z 15.7.1777 r., Zbiór rezolucyi..., 1785, s. 92.

${ }^{70}$ Rezolucja nr 149 z 19.8.1785 r., Zbiór rezolucyi..., 1788, s. 68. 
nie mogą być uchylone przez jakikolwiek inny organ sądowy. Nie znamy szerzej okoliczności skierowania zapytania do Rady Nieustającej. Pozostaje więc jedynie przypuszczać, że memoriał Ciołkowskiego mógł być efektem próby poszukiwania możliwości podważenia wyroku, jaką podjęła jedna ze stron, nieusatysfakcjonowana rozstrzygnięciem sądu polubownego.

Istotne znaczenie z uwagi na wzruszalność wyroków sądów polubownych miała rezolucja na memoriał chorążego czernihowskiego Ignacego Cieszkowskiego ${ }^{71}$, który zapytał w swoim memoriale o dopuszczalność wzruszenia dekretu kompromisarskiego, jeśli zapis na sąd polubowny sporządzony przed wydaniem przez Radę Nieustającą uniwersału z 1786 r. nie spełnił wymogów formalnych przez ten uniwersał przewidzianych - m.in. nie wskazano w nim ani czasu i miejsca odprawiania kompromisu, ani też nie wymieniono z imienia i nazwiska powoływanych przez strony arbitrów. Rada Nieustająca orzekła, że wyrazy wspomnianego uniwersału: „Przeświadczeni jesteśmy, że na wzór powagi i mocy praw samych na dal tylko przepisujących, za prawidła na przypadki następne będą mieli i brali niniejszy uniwersał Nasz obywatele prowincyi koronnych, zostając przy opisach dawnych w obiekcie kompromisowych aktów, przed niniejszym ogłoszeniem poczętych", są wystarczającą odpowiedzią na zapytanie chorążego Cieszkowskiego ${ }^{72}$. Wyraźnie więc podkreślono zasadę o niedziałaniu prawa wstecz, co w opisywanym przypadku oznaczało, że w odniesieniu do zapisów na kompromis zawartych przed datą wydania wspomnianego uniwersału strony związane były wyłącznie treścią zawartej umowy powołującej w danej sprawie sąd polubowny.

Kiedy w roku 1768 sejm warszawski uchwalił doniosłą dla organizacji sądownictwa i zasad procesu sądowego konstytucję „Złączenie Trybunału Koronnego", obok wielu wprowadzonych wówczas zmian uregulowano także kwestię postępowania w sprawach tzw. noviter reperta documentorum. Przyjęte rozwiązanie dopuszczało ponowne skierowanie do ziemstwa i rozstrzyganie przez nie spraw zakończonych prawomocnym wyrokiem, nawet trybunalskim, w przypadku pojawienia się istotnych dla sprawy (rem evincentia), nowo odkrytych, a nieznanych wcześniej stronie i sądowi dokumentów ${ }^{73}$. Materii tej Rada Nieustająca poświęciła kilkanaście rezolucji, w tym dwie związane z sądami polubownymi.

Wnioskodawca pierwszej z nich - łucki sąd ziemski - mając na względzie zarówno ustawy z 1726 i 1776 r., zakazujące, przypomnijmy, uchylania dekretów kompromisarskich, jak i wspomnianą konstytucję roku 1768, zapytał, czy korzystanie z prawa o nowo odkrytych dokumentach można na

71 Cieszkowski Ignacy Piotr h. Dołęga - chorąży czernihowski (1784-1787), Urzędnicy województw kijowskiego i czernihowskiego XV-XVIII wieku. Spisy, red. A. Gąsiorowski, oprac. E. Janas, W. Kłaczewski, Kórnik 2002, s. 151.

72 Rezolucja nr 85 z 303.1787 r., Zbiór rezolucji..., 2014, s. 110.

73 VL VII, fol. 706. 
zasadzie analogii stosować w odniesieniu do wyroków sądów polubownych. Rada Nieustająca odrzuciła taką możliwość, wyjaśniając, że założeniem konstytucji z 1776 r. było, aby „dekreta polubowne wypadłe i wypaść mające żadnej wątpliwości i naruszeniu nie podlegały, które ani ex vi noviter repertorum documentorum kwestionowane być nie powinny", thumacząc zarazem, że prawo z 1768 r. „o dekretach trybunalskich mówiące i sprawy ex noviter repertis documentis intentować pozwalające, do wzruszenia dekretów polubownych naciągane być nie może"74. Kilka lat później identyczne zapytanie skierował do Rady podsędek bracławski - Brzozowski. W odpowiedzi na nie konsyliarze $\mathrm{w}$ całości podtrzymali swoje stanowisko, przywołując zresztą treść pierwszej rezolucji ${ }^{75}$. Było to niezwykle istotne rozstrzygnięcie, z jednej strony dające gwarancję niewzruszalności wyroków i wzmacniające pozycję sądów kompromisarskich, z drugiej jednak zamykające drogę do wznowienia postępowania nawet $\mathrm{w}$ przypadkach pojawienia się dowodów, które mogły mieć kluczowe znaczenie dla sprawy.

Jednoznaczne stanowisko Rady Nieustającej, jakie zajęła w przedstawianej wyżej rezolucji (nr 1 z 1782 r.) nie wystarczyło, aby rozwiać wszelkie wątpliwości w tej kwestii. Oto bowiem w 1783 r. podkomorzy owrucki Jan Pawsza $^{76}$ zapytał konsyliarzy ,w jakiej jurysdykcyi sprawy o uchylnie kompromisów mieścić się i rozsądzać mają?”. Radzie nie pozostało nic innego, jak tylko ponownie przytoczyć treść konstytucji z 1726 r. i przypomnieć własną rezolucję w tej materii. „Przeto i forum - jak stwierdzono na koniec - dla przesądzania takowych dekretów allatenus dari nie może"77.

$\mathrm{Na}$ koniec przywołajmy rezolucję poświęconą kwestii prostowania omyłek sądu kompromisarskiego, popełnionych, jak podał autor memoriału w tej sprawie - sędzia ziemski żytomierski Adam Bukar ${ }^{78}$ - „nie z decyzyi sądu, ale ze złego u sądu tłumaczenia". Wątpliwość dotycząca tej materii pojawiła się w chwili, gdy po zakończeniu postępowania polubownego jedna ze stron udała się do sądu ziemskiego z żądaniem odesłania przez niego sprawy superarbitrowi kompromisu, w celu poprawy wspomnianych omyłek. Sąd ziemski, mając jednak na uwadze wspomniany już wyżej uniwersał z 1786 r. - ,w takim tylko razie moc superarbitrowi przyznający, gdyby kompromis rozpoczęty, a niedokończony na przyszłym z limity terminie upadł" - stanął przed dylematem, czy przekazać sprawę do superarbitra, czy też w związku z zakończeniem dzieła kompromisarskiego odrzucić żądanie powoda. Rada Nie-

${ }^{74}$ Rezolucja nr 1 z 15.11.1782 r., Zbiór rezolucyi..., 1786, s. 30.

${ }^{75}$ Rezolucja nr 104 z 11.5.1787 r., Zbiór rezolucji..., 2014, s. 127.

${ }^{76}$ Pawsza Jan h. Leliwa - podkomorzy owrucki (1765-1786), Urzędnicy województw kijowskiego i czernihowskiego XV-XVIII wieku..., s. 307.

${ }_{77}$ Rezolucja nr 188 z 29.8.1783 r., Zbiór rezolucyi..., 1786, s. 31.

78 Bukar Adam - sędzia ziemski żytomirski (1775-1792), Urzędnicy województw kijowskiego i czernihowskiego XV-XVIII wieku..., s. 134. 
ustająca nie miała w tej kwestii żadnych wątpliwości stwierdzając, iż „dekreta kompromisarskie finalnie zapadłe tej są mocy i wagi, że w rozpoznanie onych nawet Trybunały, a dopieroż ziemstwa, wdawać się nie mogą"79.

IV. Szereg zawartych w memoriałach zapytań dotyczących sądów polubownych, na które Rada Nieustająca zobowiązana była udzielać rezolucji, świadczyło o braku wystarczającej regulacji w tym zakresie. Obowiązujący stan prawny, oparty na konstytucji litewskiej z 1726 r, rozciągniętej w 1776 r. na prowincje koronne, wymagał doprecyzowania. W związku z powyższym, 7 kwietnia 1786 r. wydany został uniwersał Rady Nieustającej, w którym dokładniej uregulowano zasady funkcjonowania sądów kompromisarskich w Koronie. Jego autorzy, wskazując na podstawy swojej decyzji pisali: ,jak daleko praktyki smutne obywatelów prowincyi koronnych od celu zamierzonego odsunęły, tysiączne skargi do Nas Króla i Rady zaniesione dowodzą" Zwrócono uwagę na najczęściej pojawiające się problemy, „gdy strony niekontente $\mathrm{z}$ wyroku, dla jednego przedłużenia pieni, via gravaminis udają się do Trybunału i burzą dekreta polubowne lub gdy pod fałszywym pretekstem albo dwie zmówne z sobą strony na szkodę i rzecz trzeciej zapisują kompromis, albo pod pozorem trzeciej niby wdanej, a najczęściej zmowną transakcję wprowadzonej osoby, dobrowolnie nastałe i zeznane actus bonae voluntatis niszczą"81. Zasygnalizowano także kwestię nadużyć arbitrów, zarzucając im, że ,zapomniawszy na to, że dla przybliżenia pokoju za przyjaciół obranemi zostali, przestępują reguły mocy sobie danej, której uchybienie najmniejsze, pro nullis czyni sentencje, sądzą nieprzyzwoicie i bezprawnie" 82 . Wreszcie, winą za stan rzeczy obarczono również ,sądy same krajowe i jurysdykcyje najwyższe [które] pomimo wyraźnych ustaw i wcześniej ustanowionego rygoru nullitatis judicatorum ważą się wchodzić w rozpoznanie dekretów polubownych, reformując one, albo kasując, albo egzekucje onych wstrzymując"83. Okoliczności te skłoniły Radę Nieustającą do przypomnienia i potwierdzenia siedmiu najważniejszych ,prawideł” dotyczących organizacji i działania sądów polubownych. Ustalono, że zgodnie z obowiązującymi zasadami:

1) podstawą funkcjonowania sądu polubownego miał być tzw. zapis na kompromis jako akt bonae voluntatis, bez ograniczeń odnośnie do płci lub stanu (świeckiego lub duchownego) osoby do niego przystępującej,

2) właściwość przedmiotowa sądów polubownych nie obejmowała spraw kryminalnych, skarbu publicznego, dóbr królewskich, wszczynanych z de-

\footnotetext{
${ }^{79}$ Rezolucja nr 188 z 30.11.1787 r., Zbiór rezolucji..., 2014, s. 196.

${ }^{80}$ Uniwersał nr 305 z 7.4.1786 r., Zbiór rezolucyi..., 1788, s. 165.

81 Ibidem.

82 Ibidem.

${ }^{83}$ Ibidem.
} 
lacji instygatorów koronnych oraz spraw małoletnich, których prowadzenia w sądach zabroniło opiekunom obowiązujące prawo,

3) każda ze stron sporu powinna w zapisie precyzyjnie wskazać swoje roszczenia, wyznaczyć z imienia i nazwiska równą liczbę arbitrów oraz superarbitra, upoważniając ich do rozstrzygnięcia sprawy, podać czas oraz miejsce spotkania sądu,

4) warunkiem ważności zapisu na kompromis jest wpisanie go do akt urzędowych,

5) sprowadzeni przez strony arbitrzy i superarbiter winni przeprowadzić postępowanie, po którym zobowiązani są wydać wyrok i oblatować go następnie w aktach publicznych,

6) wszystkie sprawy przekazane sądowi polubownemu powinny być w nim rozstrzygane, jednocześnie obowiązuje bezwzględny zakaz rozpoznawania, modyfikowania lub kasowania wyroków sądów kompromisarskich przez sądy państwowe, z wyjątkiem przypadków rozbieżności zdań wśród arbitrów,

7) gdyby z jakiejkolwiek przyczyny sąd polubowny nie doszedł do skutku, a w umowie na kompromis nie zostało $\mathrm{z}$ tego tytułu zastrzeżone jego uchylenie, należy przekazać sprawę do sądu ziemskiego właściwego miejscowo lub zastrzeżonego w zapisie kompromisarskim, który w myśl Statutu Litewskiego odeśle ją ponownie do sądu polubownego.

Rada przypomniała także, zwracając się do osób ,prawa depcących i zakrętnej pieni manowcami idących (...) iż ponieważ prawa kraju wyroki sądów polubownych z powagą trybunalskich ultymarnych porównały, a w przypadku sprzeciwieństwa onym podług reguły prawa, ziemstwa czyli grody (...) równie jak i Trybunały dekreta executionis obligowane są wydawać, takowe wydane, aktem supersesyi, manifestem i listem urzędnika zaskarżone, do tym rychlejszego dodawania pomocy wojskowej pociągać nas zawsze będą"

$\mathrm{Na}$ koniec, zgodnie z decyzją Rady w celu rozpowszechnienia, kopie uniwersału miały zostać rozesłane do grodów i parafii, gdzie tekst należało umieścić na drzwiach kancelarii.

V. Funkcjonowanie sądownictwa polubownego w Pierwszej Rzeczypospolitej mocno wpisuje się w szeroko rozumianą kulturę społeczeństwa szlacheckiego. Rola jaką odgrywały kompromisy jest nie do przecenienia, a ich popularności dowodzą liczne przekazy źródłowe. Wraz ze wzrostem liczby zapisów na sądy polubowne pojawiały się jednak wątpliwości i pytania dotyczące przypadków nieznanych dotąd zwyczajowi i nieregulowanych lub nieprecyzyjnie regulowanych przez prawo stanowione. Uczestnicy postępowań polubownych starali się wówczas szukać własnych rozwiązań, co nierzadko

\footnotetext{
84 Ibidem.
} 
prowadziło do generowania kolejnych sporów między stronami lub arbitrami. Szans na stopniowe eliminowanie wszelkich problemów z tym związanych można było upatrywać w powierzeniu nowego zadania Radzie Nieustającej, która jako organ centralny uzyskała wyłączność w zakresie tłumaczenia prawa. Zarówno sądy, urzędnicy, jak i osoby prywatne korzystały z możliwości przesyłania Radzie zapytań dotyczących niejasnych norm prawnych, także w kwestii funkcjonowania sądownictwa polubownego. Przedstawione wyżej rezolucje Rady pokazują, z jakimi problemami borykano się w tej materii najczęściej i jak na zadawane pytania odpowiadali konsyliarze, pozwalają wreszcie realnie ocenić doniosłą rolę Rady Nieustającej w procesie kształtowania prawa u schyłku XVIII w.

\section{BIBLIOGRAFIA}

\section{Źródła rękopiśmienne}

AGAD, tzw. Metryka Litewska, VII, 59, 61, 64, 65.

\section{Źródła drukowane}

Czacki T., O litewskich i polskich prawach, t. II, wyd. Kazimierza Turowskiego, Kraków 1861.

Kitowicz J., Opis obyczajów za panowania Augusta III, Kraków 1951.

Matuszewicz M., Diariusz życia mego, t. I, oprac. B. Królikowski, Z. Zielińska, Warszawa 1986.

Moszczeński A., Pamiętnik do historii polskiej, Warszawa 1905.

Ostrowski T., Prawo cywilne albo szczególne narodu polskiego, t. II, Warszawa 1784.

Skrzetuski W., Prawo polityczne narodu polskiego, t. II, Warszawa 1787.

Statut Wielkiego Księstwa Litewskiego (...) teraz zaś za Najjaśniejszego Króla Stanislawa Augusta (...) przedrukowany, Wilno 1786.

Volumina Legum, t. VI, VII, VIII, Przedruk Zbioru Praw, wyd. J. Ohryzko, Petersburg 1859-1860.

Volumina Legum, t. X, wyd. Z. Kaczmarczyk, J. Matuszewski, M. Sczaniecki, J. Wąsicki, Poznań 1952.

Zbiór Praw Sąowych Andrzeja Zamoyskiego, Warszawa 1778.

Zbiór rezolucji interpretacyjnych Rady Nieustajacej z lat 1786-1788, oprac. M. Głuszak, Łódź 2014.

Zbiór rezolucyi Rady Nieustającej potrzebnych do wiadomości jurysdykcyi sądowych i obywatelów obojga narodów, Warszawa 1780.

Zbiór rezolucyi Rady Nieustającej potrzebnych do wiadomości jurysdykcyi sadowych i obywatelów obojga narodów, Warszawa 1784.

Zbiór rezolucyi Rady Nieustającej potrzebnych do wiadomości jurysdykcyi sqdowych i obywatelów obojga narodów, Warszawa 1785. 
Zbiór rezolucyi Rady Nieustającej potrzebnych do wiadomości jurysdykcyi sądowych i obywatelów obojga narodów, Warszawa 1786.

Zbiór rezolucyi Rady Nieustającej potrzebnych do wiadomości jurysdykcyi sadowych i obywatelów obojga narodów, Warszawa 1788.

\section{Opracowania}

Balzer O., Geneza Trybunału Koronnego. Studium z dziejów sądownictwa polskiego XVI wieku, Warszawa 1886.

Bardach J., Historia Państwa i Prawa Polski, t. I, Warszawa 1964.

Bednaruk W., Trybunat Koronny. Szlachecki Sąd Najwyższy w latach 1578-1794, Lublin 2008.

Borkowska-Bagieńska E., „Zbiór praw sądowych” Andrzeja Zamoyskiego, Poznań 1986.

Czaja A., Między tronem, bulawa a dworem petersburskim. Z dziejów Rady Nieustajacej 1786-1789, Warszawa 1988.

Domino S., Sądownictwo polubowne na Rusi w późniejszym średniowieczu, Warszawa 1938.

Głuszak M., Rezolucje interpretacyjne Rady Nieustającej, „Czasopismo Prawno-Historyczne", 2013, z. 2.

Godek S., III Statut Litewski w dobie porozbiorowej, Warszawa 2012.

Grajewski H., Granice czasowe mocy obowiazującej norm dawnego prawa polskiego, Łódź 1970.

Konopczyński W., Geneza i ustanowienie Rady Nieustającej, Kraków 1917.

Korzon T., Wewnętrzne dzieje Polski za Stanisława Augusta, t. IV, Kraków-Warszawa 1897.

Kutrzeba S., Historia źródeł dawnego prawa polskiego, t. I, Lwów 1925.

Łaszewski R., Sejm Polski w latach 1764-1793, Poznań 1973.

Michalski J., Reforma sadownictwa na sejmie konwokacyjnym 1764 roku, [w:] idem, Studia historyczne z XVIII i XIX wieku, t. I, Polityka i społeczeństwo, Warszawa 2007.

Michalski J., Studia nad reforma sadownictwa i prawa sadowego w XVIII w., Wrocław-Warszawa 1958.

Moniuszko A., Rosner A., Historia polubownego rozwiązywania sporów na ziemiach polskich. Zarys problematyki, [w:] Mediacje. Teoria i praktyka, red. E. Gmurzyńska, R. Morek, Warszawa 2014.

Oficerowie Rzeczypospolitej Obojga Narodów 1777-1794. Spisy, t. I, cz. 1, M. Machynia, C. Srzednicki, Wojsko Koronne. Sztaby i kawaleria, Kraków 2002.

Płaza S., Historia prawa w Polsce na tle porównawczym, cz. I, Kraków 2002.

Rafacz J., Dawny proces polski, Warszawa 1925.

Rosner A., Tradycja staropolskiego sądownictwa polubownego - Próba zarysowania problemu, [w:] Sprawiedliwość naprawcza. Idea. Teoria. Praktyka, red. M. Płatek, M. Fajst, Warszawa 2005.

Rymaszewski Z., Czynności woźnego sądowego, Warszawa 2010.

Uruszczak W., Historia państwa i prawa polskiego, t. I, Warszawa 2010. 
Urzędnicy centralni i nadworni Polski XIV-XVIII wieku. Spisy, red. A. Gąsiorowski, oprac. K. Chłapowski, S. Ciara, Ł. Kądziela, T. Nowakowski, E. Opaliński, G. Rutkowska, T. Zielińska, Kórnik 1992.

Urzędnicy województw kijowskiego i czernihowskiego XV-XVIII wieku. Spisy, red. A. Gąsiorowski, oprac. E. Janas, W. Kłaczewski, Kórnik 2002.

Urzędnicy województwa sandomierskiego XV-XVIII wieku. Spisy, red. A. Gąsiorowski, oprac. K. Chłapowski, A. Falniowska-Gradowska, Kórnik 1993.

Zakrzewski A.B., Wielkie Księstwo Litewskie (XVI-XVIII w.). Prawo - Ustrój - Spoteczeństwo, Warszawa 2013.

Zienkowska K., Karwosiecki Gabriel Antoni, Polski Słownik Biograficzny, t. XII, Kraków 1966-1967.

THE ISSUE OF ARBITRATION TRIBUNALS

IN THE RESOLUTIONS OF THE PERMANENT COUNCIL (1776-1788)

\section{Summary}

The arbitration tribunals, due to their common character, made up one of the foundations of social life in the Polish-Lithuanian Commonwealth. Acting on the basis of a contract drawn up and concluded between the parties, it constituted an attractive alternative to the idle functioning of state courts. A number of advantages to solving disputes through compromise made them a popular and frequently used mean of solving conflicts in the $18^{\text {th }}$ century. A valuable source of information about the arbitration tribunals are the resolutions published between 1776 and 1788 by the Permanent Council. The aforementioned resolutions contained interpretations of abstruse and questionable provisions of law. Numerous memorials were addressed to the Council and they formulated questions pertaining to various spheres. One of the most frequently brought up issues was the organization and the rules of functioning of the arbitration tribunals. Consequently, the analysis of judicial decisions of the Permanent Council enabled extensive supplementation of current knowledge about this important, from the point of view of the nobility, legal institution.

\section{LA QUESTION DE L'ARBITRAGE DANS LES RÉSOLUTIONS DU CONSEIL PERMANENT (1776-1788)}

\section{Rés umé}

Les tribunaux d'arbitrage (de compromis) en raison de son caractère universel constituaient l'un des fondements de la vie sociale en République de Deux Nations. En basant sur des accords élaborés et conclus entre les parties opposantes, ils repré- 
sentaient une alternative intéressante aux tribunaux sanctionnés par l'administration d'État qui travaillaient trop lentement.

$\mathrm{Au} \mathrm{XVIII}$ siècle, un certain nombre d'avantages découlant de la résolution à l'amiable des litiges ont rendus cette institution populaire ; ainsi elle est devenue un outil souvent utilisé pour résoudre des conflits. Les résolutions du Conseil permanent, adoptées dans les années 1776-1788 constituent une source précieuse d'informations sur les tribunaux d'arbitrage. Elles contiennent une interprétation des dispositions de la loi douteuses et peu claires. Dans les mémoires adressées au Conseil, leurs auteurs ont formulé de nombreuses questions concernant différents domaines du droit, et l'un des sujets le plus fréquemment abordés était l'organisation et le fonctionnement des tribunaux d'arbitrage. L'analyse de la jurisprudence du Conseil permanent nous permet donc de compléter de manière considérable les connaissances actuelles sur le fonctionnement de cette institution de droit, très importante du point de vue de la noblesse. 